
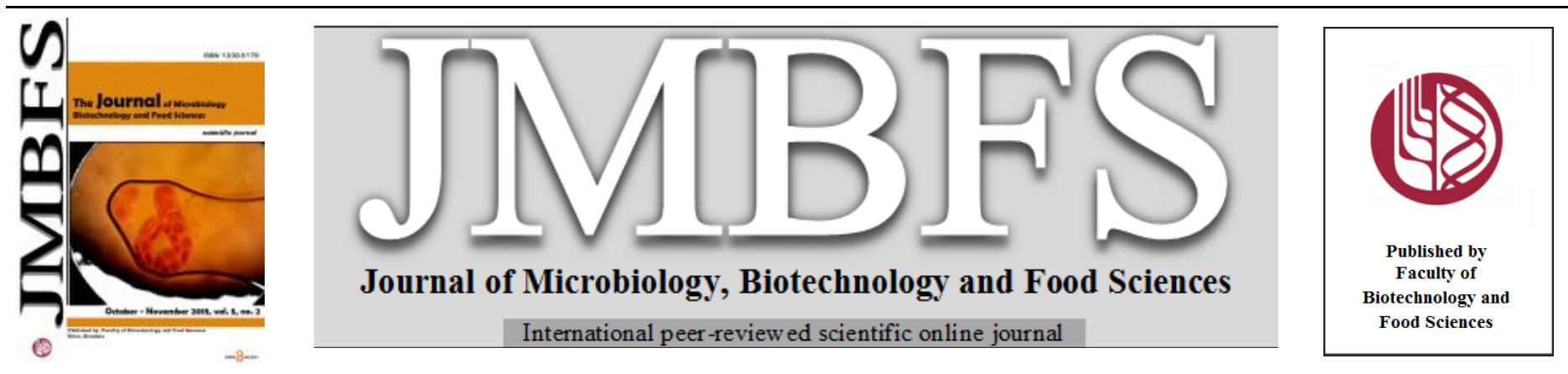

\title{
PROBIOTIC ATTRIBUTES OF THE NEWLY ISOLATED LACTIC ACID BACTERIA FROM INFANTS'GUT
}

\author{
Bijender Kumar Bajaj ${ }^{1,2}$, Konika Razdan ${ }^{1}$, Ingmar JJ Claes ${ }^{2}$ and Sarah Lebeer ${ }^{2}$
}

\author{
$\operatorname{Address(es):~}$ \\ ${ }^{1}$ School of Biotechnology, University of Jammu, Jammu- 180006 INDIA Phone +91-94191-02201; Fax: +91-191-2456534. \\ ${ }^{2}$ Department of Bioscience Engineering, University of Antwerp, Groenenborgerlaan 171, B-2020, Antwerp, Belgium.
}

*Corresponding author: bajajbijenderk@gmail.com

doi: 10.15414/jmbfs.2015.5.2.109-115

\section{ARTICLE INFO}

Received 15. 7. 2014

Revised 18. 4. 2015

Accepted 16. 7. 2015

Published 1. 10. 2015

Regular article

OPEN $\partial_{\text {ACCESS }}$

\begin{abstract}
The gut microbiota intimately interacts with the host and influences physiological, metabolic, genetic, and immunological attributes. In the current study, analysis of fecal samples from healthy breast fed infants showed that lactic acid bacteria constitute the most abundant bacterial spp. in the infant gut (Lactobacillus plantarum being the most predominant) contrary to the established reports that Bifidobacterium spp. are mostly predominant in the infants' gut. Evaluation of lactic acid bacteria (LAB) isolates for important probiotic characteristics showed that several of the isolates were well equipped with desirable probiotic attribute viz. ability to grow at the gut $\mathrm{pH}$, and at high $\mathrm{NaCl}$, bile and phenol concentrations. Some of the LAB isolates expressed functional properties like high hydrophobicity, cholesterol lowering ability, exopolysacharide producing ability, and antimicrobial potential against human pathogens. Three LAB isolates found to be superlative on probiotics attributes were identified as Enterococcus faecium FS-1.1, E. faecium FS-2.0, and E. faecium FS-4.0, based on 16S rDNA sequence analysis. Furthermore, the fecal samples of breast fed infants showed lower level of $\beta$ glucuronidase and higher level of $\beta$-glucosidase as compared to the formula fed infants, thus, reflecting the importance of breast-feeding towards general health and well being of infants.
\end{abstract}

Keywords: Lactic acid bacteria, breast/formula fed infants, hydrophobicity, exopolysaccharide, $\beta$ - glucuronidase, $\beta$-glucosidase

\section{INTRODUCTION}

The microbiota of a newborn develops rapidly, and is strongly dependent on the mother's microbiota, mode of birth, physical environment and hygiene during birth, and subsequently influenced by feeding practices and rearing environment of the infant (Salminen et al., 2005; Ozen and Dinleyici, 2015). The bacteria which are found during the various stages of colonization include members of the genera Bifidobacterium, Enterococcus, Clostridium and Enterobacter, among others (Weng and Walker, 2006; Bajaj et al., 2015). Bifidobacteria constitute the largest group of bacteria in the intestine of infants, however, their number actually declines in the human body with age (Ishibashi et al., 1997). In breastfed infants bifidobacteria constitute about $90 \%$ of their intestinal bacteria; however, this number is lower in formula-fed infants (Zinedine and Faid, 2007) When breast-fed infants' diet is changed to cow's milk and solid food, bifidobacteria are joined by other bacteria found in the human body such as Bacteroides, streptococci and lactobacilli, and others. Lower number of bifidobacteria in formula-fed infants attributes towards a higher risk of diarrhea and allergies that is usually associated with babies who aren't breast-fed. In addition, because bifidobacteria produce lactic acid instead of gas (unlike $E$. coli), infants and people in general with more bifidobacterial population than other bacteria may have less gas and digestive problems (Hussey et al., 2011) The characterization of fecal enzymes has been used as an indicator for the gut microflora composition, and its association with hosts' health status, suggesting that gut microbiota is stout and unified system (Mc Intosh et al., 2012).

The foremost endeavor of the current investigation was to study the dominan bacteria in the breast-fed infants born out of the vaginal mode of delivery, and to characterize the probiotic potential of the isolates from infant feces; in addition fecal enzyme status of the infants based upon difference in the age span and feeding habits was also investigated. Probiotics are live microorganisms (single/mixed cultures) which impart multiple health benefits to the consumer animals or humans. Probiotics include different lactic acid bacteria viz. Lactobacillus spp., Bifidobacterium, and the yeast Saccharomyces boulardii, among several others. The selection of probiotic strains from appropriate sources depending on the target population, such as neonates and children whose gut microbiota may differ from that of healthy adults, constitutes a promising approach (O'Toole and Claesson, 2010). In this regard most of the strains currently available have targeted the adult population but fewer strains have been selected for other groups of age, such as human neonates, where the applications of probiotics may have a great positive impact (O'Toole and Claesson, 2010). Demand of probiotics has increased in recent years due to enhanced availability of evidences for health benefits. Isolation of novel strains of probiotics with proficient health benefitting characteristics has gained immense research impetus considering that health benefits of probiotics(s) cannot be generalized i.e. health attributes earmarked in one strain or species may not be necessarily present in other members of genus/species or strains (Bajaj et al., 2014; Bajaj et al., 2015). Therefore, bioprospecting of novel probiotics strains from unexplored ecological niches would be advantageous for targeting novel strains with potential functional characteristics for future applications in food/pharmaceutical industries. In addition, this practice may help investigating taxonomic characteristics of microbial isolates/strains for potentially novel biotechnological applications. Sources for isolation of probiotics could be immensely diverse e.g. traditional fermented foods, plant, animal, human and marine sources. Proficient probiotic(s) must possess certain desired characteristics like ability to survive in gut, adhesion ability in intestine, antagonistic potential against pathogens, devoid of antibiotic resistance, exopolysaccharide producing ability, among others. Furthermore, should a single organism not possess all such desired features, a combination may be used as probiotics. Current article describes the recent developments in the area of bioprospecting of probiotics (Bajaj et al., 2014).

Gastrointestinal (GI) tract infections constitute one of the major causes of morbidity and mortality among infants/children worldwide. Every year around $1,575,000$ children under the age of five die due to severe diarrhea and dehydration representing $15 \%$ of the 10.5 million deaths per year of children in this age group (Lopez et al., 2006). Certain probiotics are found to be helpful in preventing and treating some types of bacteria-induced diarrhea because of their ability to alter the activity of the intestinal microflora and compete with the potential pathogens (Marteau et al., 2001; Bajaj et al., 2015). Therefore targeting of probiotics specific for infants/children has been emphasized. Furthermore, the quest for novel efficacious probiotic strains is a continuous process, keeping in view the huge diversity among probiotic strains with respect to their health augmenting attributes. Thus, new probiotic strains with appropriate properties may be identified for potential infant applications. 


\section{MATERIALS AND METHODS}

\section{Sample collection isolation and identification of bacteria}

Fecal samples of healthy infants borne out of vaginal course of delivery were collected from the Department of Paediatrics, Government Medical College and Allied Hospitals, Jammu, in sterile sample containers and maintained at $4{ }^{\circ} \mathrm{C}$ and assayed within an hour or two of collection. The consent of the parents of the infants was taken before the samples were collected and the medical history of the infant and the mother was documented. It was ensured that both the mother and the infant had not taken any antibiotic for last 2 weeks.

One gram of fecal sample was suspended in saline $(0.85 \% \mathrm{w} / \mathrm{v}, \mathrm{NaCl})$, serially diluted, and spread plated on MRS agar supplemented with L- cysteine hydrochloride $(0.05 \%, \mathrm{w} / \mathrm{v})$ and gentamycin $(100 \mathrm{mg} / \mathrm{L})$. Plates were incubated in an anaerobic chamber (HiMedia Laboratories Pvt. Ltd, India), at $37^{\circ} \mathrm{C}$ for $48-72$ h. The colonies obtained were purified on MRS agar and examined microscopically. The selected isolates were maintained in skimmed milk $(10 \%$, $\mathrm{w} / \mathrm{v}$ ) at $4{ }^{\circ} \mathrm{C}$ for smaller duration, and at $-20^{\circ} \mathrm{C}$ in skimmed milk supplemented with glycerol $(50 \%, \mathrm{w} / \mathrm{v})$ for long term storage.

The isolates were studied for Gram reaction, catalase test, spore staining, and growth at $10^{\circ} \mathrm{C}$ and $45^{\circ} \mathrm{C}$ for $48 \mathrm{~h}$, and production of $\mathrm{CO}_{2}$ from glucose (Patil $\boldsymbol{e t}$ al., 2010). $\beta$-galactosidase and fructose 6-phosphate phosphoketolase activity (F6PPK) tests were done (Martnez et al., 2012) for the preliminary examination of lactic acid bacteria (LAB). The ability of LAB to ferment various carbohydrates was examined using HiCarbohydrate ${ }^{\mathrm{TM}}$ kit (HiMedia Laboratories Pvt. Ltd, India). Interpretation of fermentation profiles of carbohydrates was done using the PIBWin software, which is the ID tool used to run the Ashex matrix. Ashex is an enormous system of excel worksheets, formed by analyzing and compiling data from hundreds of biochemical tests (http://www.som.soton.ac.uk/staff/tnb/pib.htm).

The selected LAB isolates were identified based upon 16S rDNA sequence analysis. DNA was isolated (Hi Media DNA extraction kit) and PCR-amplified using the universal primers: forward, lac1-27F 5, AGAGTTTGATCCTGGCTCAG and reverse, lac 1-1492R 5'TACGGYTACCTTGTTACGACT (IDT/Promega) in a thermocycler (Eppendorf, Mastercycler gradient). PCR reaction was run for 30 cycles. The following thermal profile was used for the PCR: denaturation at $94^{\circ} \mathrm{C}$ for $4 \mathrm{~min}$, primer annealing at $52^{\circ} \mathrm{C}$ for $45 \mathrm{sec}$ and extension at $72^{\circ} \mathrm{C}$ for $1 \mathrm{~min}$ and $30 \mathrm{sec}$. The final cycle included extension for $10 \mathrm{~min}$ at $72^{\circ} \mathrm{C}$. The amplified product the ( 1,500 bases) was sequenced (Department of Biochemistry, University of Delhi, South Campus). The sequence was subjected to Mega Blast analysis from Genbank data base of NCBI, and dendrogram generated (Mega5).

\section{Growth studies at different $\mathrm{pH}$, and in presence of $\mathrm{NaCl}$, bile salt and phenol}

For assessing the ability of isolated $\mathrm{LAB}$ to grow over (and tolerate) wide range of $\mathrm{pH}(2,4$ and 8$), \mathrm{NaCl}(4,8$ and $12 \%$, w/v), bile salts $(2$ and $4 \%, w / v)$ and phenol $(0.2,0.4$ and $0.6 \%, \mathrm{w} / \mathrm{v})$, the MRS broth used for growth studies was added with corresponding amounts of inhibitory substances viz. $\mathrm{NaCl}$, bile salts or phenol or adjusted at desired $\mathrm{pH}$. The LAB cultures were activated by growing them in MRS broth for $18 \mathrm{~h}\left(\mathrm{~A}_{600}, 0.8\right)$ and then inoculated (@1 \%, v/v) into different MRS broth having varying $\mathrm{pH}, \mathrm{NaCl}$, bile salts or phenol concentration. Incubation at $37^{\circ} \mathrm{C}$ under static conditions was given for $24 \mathrm{~h}$ and growth was measured spectrophotometerically at $660 \mathrm{~nm}$ (UV-VIS 1800, Shimadzu, Japan). Growth in plain MRS broth at pH 6.5 served as control.

\section{Hydrophobicity of the LAB isolates}

Cell surface hydrophobicity was determined based on the method described by (Aswathy et al., 2008) with slight modification. LAB isolates were grown in MRS broth, centrifuged $(7500 \times \mathrm{g}$ for $5 \mathrm{~min}$, Sigma, 3K30) and the cell pellet was washed thrice with ringer solution (each w/v, $\mathrm{NaCl} 6 \%, \mathrm{KCl} 0.0075 \%, \mathrm{CaCl}_{2}$ $0.01 \%$ and $\mathrm{NaHCO}_{3} 0.01 \%$ ) and suspended in the ringer solution and examined for absorbance at $580 \mathrm{~nm}$. Cell suspension was mixed with n-hexadecane (3:1) in a cyclomixer for $2 \mathrm{~min}$ and allowed to stand for $30 \mathrm{~min}$ to get the two phases separated. The lower phase was examined spectrophotometrically $(580 \mathrm{~nm})$. The percent hydrophobicity of strain adhering to n-hexadecane was calculated using the following equation:

$$
\text { Percent hydrophobicity }=\frac{\mathrm{A}_{580}(\mathrm{bm})-\mathrm{A}_{580}(\mathrm{wh})}{\mathrm{A}_{580}(\mathrm{bm})} \times 100
$$

Where: bm - before mixing, wh - with hexadecane
For determining antibacterial activity, the isolates were grown in MRS broth for $18 \mathrm{~h}$ at $37^{\circ} \mathrm{C}$ under static conditions. Cultural broth was centrifuged $(8000 \times \mathrm{g}$ for $5 \mathrm{~min}$ ) and the supernatant was filtered through a bacterial filter (Whatman, 0.22 $\mu)$. The filtrate was used for assaying the antimicrobial activity after adjusting the $\mathrm{pH}$ to 6.4. The test organisms (Bacillus subtilis, B. cereus, Escherichia coli, Pseudomonas aeruginosa, P. alkaligenes, Staphylococcus aureus and Streptococcus sp., procured from culture collection of Fermentation Biotechnology Lab. of School of Biotechnology, University of Jammu, Jammu) were grown for $18 \mathrm{~h}$ at $37^{\circ} \mathrm{C}$ in Luria-Bertani broth $\left(\mathrm{A}_{600} 0.6\right)$ and spread plated on Mueller-Hinton agar. The wells $(6 \mathrm{~mm}$ each) were cut on the lawn of spread culture and the cultural filtrate obtained above was poured (@45 $\mu 1)$ into each well, allowed the filtrate to diffuse for 2-3 h, and then plates were incubated for $24-48 \mathrm{~h}$ at $37^{\circ} \mathrm{C}$. The appearance of zone of inhibition around the well was suggestive of antimicrobial activity and the same was measured.

\section{Cholesterol-lowering ability of LAB isolates}

MRS broth containing L-cysteine hydrochloride $(0.05 \%$, w/v) was supplemented with pre-filtered $(0.45 \mu \mathrm{m}$ Whatmann) soluble cholesterol (polyoxyethanylcholesterol sebacate, Sigma, USA) and inoculated with LAB culture to attain final concentration of $10^{8} \sim 10^{9} \mathrm{CFU} / \mathrm{ml}$ of solution. Incubation was given anaerobically at $37^{\circ} \mathrm{C}$ for $24 \mathrm{~h}$. After incubation the cultures were centrifuged (8000 $\mathrm{g}$ for $10 \mathrm{~min}$ ), and the supernatant was assayed for residual cholesterol content (Rudel and Morris, 1973) Uninoculated cholesterol-MRS broth served as the control.

\section{Exopolysaccharides (EPS) production by LAB isolates}

EPS producing ability of LAB was assessed (Frengovaa et al., 2002). Selected isolates were grown overnight in modified MRS broth (glucose and lactose, each (a) $10 \%, \mathrm{w} / \mathrm{v})$ for $37{ }^{\circ} \mathrm{C}$ and centrifuged $(11000 \times \mathrm{g}$ for $10 \mathrm{~min})$ to obtain the supernatant. Two volumes of cold ethanol was added to the supernatant and stored overnight at $4{ }^{\circ} \mathrm{C}$. Precipitated material was collected by centrifugation $(2500 \times \mathrm{g}$ for $20 \mathrm{~min})$ resuspended in demineralised water and re-precipitated by mixing with 2 volumes of cold ethanol, and allowed to stand for 12-18 $\mathrm{h}$. The precipitate was separated by centrifugation $(2500 \times \mathrm{g}$ for $20 \mathrm{~min})$, pellets were air dried and assayed for total carbohydrate content using the phenol-sulfuric acid procedure (Dubois et al., 1956).

\section{Fecal analysis of enzyme ( $\beta$-glucuronidase and $\beta$-glucosidase)}

One gram of fecal sample was diluted in phosphate buffered saline and used as an equivalent to crude enzyme preparation for analysis. $\beta$-glucuronidase (EC 3.2.1.31) was assayed by using phenolphthalein- $\beta$-D-glucopyranosiduronic acid as substrate (in $0.1 \mathrm{~mol} / \mathrm{L}$ of potassium phosphate, $\mathrm{pH} 6.8$ ), and $\beta$-glucosidase (EC 3.2.1.21) was assayed by using $p$-nitrophenyl- $\beta$-D-glucopyranoside as substrate (in $0.1 \mathrm{~mol} / \mathrm{L}$ potassium phosphate, $\mathrm{pH} 7.4$ ) by using spectrophotometric method (Freeman, 1986). The activity of $\beta$-glucuronidase and $\beta$-glucosidase was expressed in terms of amount of products i.e. phenolphthalein and $p$-nitrophenol, respectively, generated (millimoles) from their respective substrates, per $\mathrm{h}$ per $\mathrm{mg}$ of protein. All analytical experiments were run in triplicate, and data presented is the mean of three values.

\section{RESULTS}

Isolation and biochemical analysis of $\mathrm{LAB} / \mathrm{bifidobacteria}$ from infant fecal samples

A total of 50 infant fecal samples (exclusively breast fed infants and borne by vaginal mode of delivery) were used for isolation of bacteria. The samples were enriched in MRS broth and a total of 135 bacterial isolates were obtained on the MRS agar plates. All the isolates were purified and maintained on skimmed milk for further studies. Based upon biochemical and physiological analysis of a total of 93 bacterial isolates, 77 of the isolates were identified as LAB $(82 \%)$ while 16 (approximately 18\%) isolates were earmarked as Bifidobacterium sp. (Zinedine and Faid, 2007) as shown in Table 1. Among lactobacilli Lactobacillus plantarum was the most predominating sp. (18 isolates), and was followed by $L$. casei subsp. casei and L. brevis (6 isolates, each), L. casei (4 isolates), L. fermentum (3 isolates) and L. helveticus ( 2 isolate each); one isolate each of $L$. casei subsp. alactosus, L. bulgaricus and L. viridescens was reported. Among the enterococci $E$. faecium was found to be the predominant (14 isolates), followed by E. durans (11 isolates) and E. faecalis (10 isolates). 
Table 1 Lactic acid bacteria and bifidobacteria isolates from infant fecal samples

\begin{tabular}{lll}
\hline Infant fecal isolates & Number of isolates & Identification \\
\hline FS1.2, FS 3.2, FS 4.4, FS 4.7, FS 5.2, FS 11.4, FS12.1, FS14.1, FS14.4, FS17.2, & \multirow{2}{*}{ Lactobacillus plantarum } \\
FS 29.3, FS 6.3, FS11.2, FS15.1, FS20.1, FS 23.2, FS 29.4, FS 31.3 & 6 & Lactobacillus brevis \\
\hline FS 9.1, FS 10.4, FS 20.4, FS 17.1, FS 28.1, 29.1. & 6 & Lactobacillus casei subsp. casei \\
\hline FS 13.1, FS 16.4, FS 24.1, FS 27.2, FS 25.6, FS 34.3 & 4 & Lactobacillus casei \\
\hline FS 12.5, FS 22.2, FS 30.2, FS 32.1 & 3 & Lactobacillus fermentum \\
\hline FS 15.2, FS 31.1, FS 50.1, & 2 & Lactobacillus helveticus \\
\hline FS 30.1, FS 12.6, & 1 & Lactobacillus casei subsp. alactosus \\
\hline FS 33.1 & 1 & Lactobacillus bulgaricus \\
\hline FS 33.2 & 1 & Lactobacillus viridescens \\
\hline FS 34.2 & \multirow{2}{*}{ Enterococcus faecalis } \\
\hline FS 37.1, FS 37.2, FS 38.2, FS 43.1, FS 44.1, FS 46.2, FS 50.2, FS 31.4, FS 47.2, & \multirow{2}{*}{ Enterococcus faecium } \\
\hline FS 1.1, FS2.0, FS4.0 FS 36.1, FS 38.1, FS 45.3, FS 46.1, FS 49.1, FS 23.1, FS & \multirow{2}{*}{ Enterococcus durans } \\
25.1, FS 43.2, FS 47.1, FS17.3, FS-50.4 & 11 & \multirow{2}{*}{ Bifidobacterium spp. } \\
\hline FS 35.1, FS 39.1, FS 40.2, FS 42.1, FS 42.2, FS 44.3, FS 47.3, FS 23.3, FS 25.3, & \multirow{2}{*}{16} & \\
\hline FS 49.2,FS-6.1 12.2, FS 13.2, FS 13.3, FS 16.1, FS 31.5, FS 34.1, FS 34.4, FS 38.3, FS 38.4, & \\
FS 39.2, FS 39.3, FS 1.3, FS 1.4, FS 1.5, FS 4.2, FS 4.6 &
\end{tabular}

\section{Growth study of LAB/bifidobacteria isolates under (gut like) inhibitory} conditions

Among LAB isolates, 11 grew appreciably at $\mathrm{pH} 2$ and $4\left(\mathrm{~A}_{600}, 0.5-0.1\right), 21$ showed average growth $\left(\mathrm{A}_{600} 0.1-0.05\right)$ while the rest grew relatively slower $\left(\mathrm{A}_{600}\right.$ 0.05 or less). L. plantarum FS-1.2, E. faecium FS-2.0 and L. plantarum FS-4.4 showed maximum growth. Sixty one isolates grew well at $4 \% \mathrm{NaCl}$ concentration wherein isolate $L$. casei subsp. casei FS-13.1 ( $\left.\mathrm{A}_{600} 0.570\right)$ and $L$. plantarum $\mathrm{FS}-3.2$ showed maximum growth $\left(\mathrm{A}_{600}\right.$ 0.473); 33 of the LAB isolates showed good growth at $8 \% \mathrm{NaCl}\left(\mathrm{A}_{600}, 0.5-0.1\right)$ while only 2 isolates $L$. plantarum FS 12.1 and $L$. casei FS 12.5 grew at $12 \% \mathrm{NaCl}$. Sixty seven LAB isolates showed growth (absorbance of 0.1 or above) at $0.2 \%$ phenol while only $18 \mathrm{did}$ so at $0.4 \%$ of phenol. As the phenol concentration further increased $(0.6 \%)$ growth of all the isolates declined. E. faecium FS-4.0 was the lone isolate which showed appreciable growth at $0.6 \%$ of phenol. Sixty isolates grew well at $2 \%$ bile while only three isolates (E. faecium FS-4.0, L. casei FS-32.1 and E. faecium FS$38.1)$ showed appreciable growth at $4 \%$ bile concentration. Thus, several of the
Lab isolates were able to withstand and grow over varying range of inhibitory agents/conditions generally encountered in the GI environment.

\section{Hydrophobicity of the $\mathrm{LAB} / \mathrm{bifidobacteria}$ isolates}

All LAB and bifidobacteria isolates were evaluated for the degree of hydrophobicity in order to examine their adhesion property in the gut. The bacterial isolates displayed varying level of hydrophobicity (Table 2). The isolate L. plantarum FS 1.2 showed the maximum hydrophobicity $(92.6 \%)$ and was followed by Bifidobacterium sp. FS 4.6 (90.7\%), E. faecium FS 46.1 (90.2\%), L. viridescens FS $34.2(87.2 \%)$, L. helveticus FS 30.1 (84.0\%), L. fermentum FS $15.2(83.4 \%)$, L. plantarum FS $3.2(82.1 \%)$, L. brevis FS $29.1(82.0 \%)$ and $E$ faecium FS $1.1(80.1 \%)$. Forty six of the LAB isolates had hydrophobicity in the range of $50-80 \%$ while rest of the isolates displayed hydrophobicity that was less than $50 \%$.

Table 2 Functional attributes (hydrophobicity, EPS producing, and cholesterol-lowering ability) of probiotic lactic acid bacteria isolates from infant fecal samples

\begin{tabular}{|c|c|c|c|c|c|}
\hline LAB isolates & $\begin{array}{c}\text { Hydrophobicity } \\
(\%)\end{array}$ & LAB isolates & EPS (mg/l) & LAB isolates & cholesterol reduction $(\%)$ \\
\hline L. plantarum FS 1.2 & $92.6 \pm 0.25$ & L. plantarum $\mathrm{FS} 1.2$ & $814 \pm 11.51$ & L. plantarum FS 1.2 & $59.6 \pm 1.25$ \\
\hline E. faecium FS 46.1 & $90.2 \pm 0.15$ & E. durans FS 6.1 & $647 \pm 13.22$ & L. plantarum FS 4.7 & $58.09 \pm 0.8 .5$ \\
\hline L. viridescens FS 34.2 & $87.2 \pm 0.02$ & L. casei subsp. casei FS 25.6 & $619 \pm 14.54$ & E. faecalis FS 37.1 & $58.02 \pm 0.92$ \\
\hline L. helveticus FS 30.1 & $84.0 \pm 0.35$ & E. faecalis FS 50.1 & $616 \pm 12.42$ & L. casei FS 12.5 & $57.65 \pm 1.12$ \\
\hline L. fermentum FS 15.2 & $83.4 \pm 0.22$ & E. durans FS 39.1 & $570 \pm 13.73$ & L. helveticus FS 12.6 & $57.02 \pm 1.48$ \\
\hline L. plantarum FS 3.2 & $82.1 \pm 0.55$ & L. casei subsp casei FS 27.2 & $550 \pm 9.91$ & E. faecalis $\mathrm{FS} 37.2$ & $56.20 \pm 1.32$ \\
\hline L. brevis FS 29.1 & $82.0 \pm 0.11$ & L casei FS 22.2 & $523 \pm 14.96$ & L. casei FS 22.2 & $54.42 \pm 0.65$ \\
\hline E. faecium FS 1.1 & $80.1 \pm 0.17$ & L. casei subsp casei FS 13.1 & $512 \pm 11.11$ & L. casei subsp. casei FS 25.6 & $53.36 \pm 1.51$ \\
\hline E. durans FS 39.1 & $79.1 \pm 0.45$ & E. faecalis FS 38.2 & $512 \pm 8.59$ & L. plantarum FS 14.1 & $53.20 \pm 0.87$ \\
\hline L. plantarum FS 33.1 & $78.5 \pm 0.63$ & E. faecium $\mathrm{FS} 2.0$ & $510 \pm 6.67$ & L. helveticus FS 30.1 & $52.94 \pm 1.05$ \\
\hline L. brevis FS-10.4 & $78.3 \pm 0.78$ & L. fermentum FS 15.2 & $509 \pm 10.14$ & L. plantarum FS-6.3 & $49.79 \pm 1.81$ \\
\hline
\end{tabular}

\section{EPS producing ability of the LAB and bifidobacteria isolates}

Various LAB isolates showed varying level of EPS production. L. plantarum FS 1.2 showed maximum level of EPS production $(814 \mathrm{mg} / \mathrm{l})$, and was followed by E. durans FS $6.1(647 \mathrm{mg} / \mathrm{l})$, L. casei subsp. casei FS $25.6(619 \mathrm{mg} / \mathrm{l})$, E. faecalis FS $50.1(616 \mathrm{mg} / \mathrm{l})$, E. durans FS $39.1(570 \mathrm{mg} / \mathrm{l})$, L. casei subsp casei FS $27.2(550 \mathrm{mg} / \mathrm{l})$, L casei FS $22.2(523 \mathrm{mg} / \mathrm{l})$, L. casei subsp casei $\mathrm{FS} 13.1$ $(512 \mathrm{mg} / \mathrm{l})$, E. faecalis $\mathrm{FS} 38.2(512 \mathrm{mg} / \mathrm{l})$, E. faecium $\mathrm{FS} 2.0(510 \mathrm{mg} / \mathrm{l}), L$. fermentum FS $15.2(509 \mathrm{mg} / \mathrm{l})$ and L. helveticus FS 12.6 (506 mg/l) (Table 2). Eighty eight of the isolates produced EPS in the range of $200-500 \mathrm{mg} / \mathrm{l}$ while rest of the isolates yielded EPS that was less than $200 \mathrm{mg} / \mathrm{l}$

\section{Cholesterol-lowering ability of LAB and bifidobacteria isolates}

All the LAB and bifidobacteria isolates in the current study expressed cholesterol lowering ability up to a varying extent (Table 2). The isolate L. plantarum FS 1.2 showed maximum cholesterol reduction (59.6\%) and was followed by isolates $L$. plantarum FS 4.7 (58.09\%), E. faecalis FS 37.1 (58.02\%), Bifidobacterium sp. FS 38.3 (57.91\%), L. casei FS 12.5 (57.65\%), L. helveticus $\mathrm{FS} 12.6$ (57.02\%), E. faecalis FS 37.2 (56.20\%), Bifidobacterium sp. FS 1.3 (54.97\%), L. casei FS 22.2
(54.42\%), L. casei subsp. casei FS 25.6 (53.36\%), L. plantarum FS 14.1 $(53.20 \%)$, L. helveticus FS 30.1 (52.94\%), Bifidobacterium spp. FS 13.3 $(52.67 \%)$ and Bifidobacterium sp. FS $24.1(52.28 \%)$. Thirty five isolates expressed cholesterol reducing ability of $40-52 \%$, while rest of the isolates showed cholesterol reducing ability of $40 \%$ or less. Cholesterol at $470 \mathrm{mg} / \mathrm{l}$ was used as control.

\section{Antibacterial activity of LAB isolates}

Most of the LAB isolates showed antagonistic activity against potential pathogens of human health significance. Only a few isolates showed substantial growth inhibition of the pathogens (inhibitory zone size of $10 \mathrm{~mm}$ or above). Five isolates (Lactobacillus plantarum 1.2, Lactobacillus brevis 28.1, Enterococcus durans 23.3, Enterococcus faecium 43.2, Enterococcus faecalis 50.3) showed maximum inhibition zone $(10 \mathrm{~mm}$ or above) against $S$. aureus; four isolates (Lactobacillus helveticus FS 30.1, Enterococcus durans 42.1, Enterococcus faecalis 50.2, Enterococcus faecalis 31.4) showed against E. coli; three isolates (Lactobacillus plantarum 5.2, Lactobacillus casei subsp casei 13.1, Lactobacillus plantarum 14.1) showed growth inhibition against P. aeruginosa; and three LAB isolates (Lactobacillus plantarum 5.2, Lactobacillus plantarum 
14.1, Lactobacillus casei subsp casei 13.1) showed antibacterial activity against Klebsiella sp., and two isolates (Lactobacillus plantarum 14.1, Lactobacillus plantarum 29.3) inhibited E. faecalis, and two other isolates (Enterococcus faecium 1.1, Lactobacillus plantarum 14.4) inhibited B. subtilis. Majority of the LAB isolates expressed moderate antagonistic activity against the pathogens examined (inhibition zone $5-10 \mathrm{~mm}$ ) while others exhibited weak inhibitory activity (inhibition zone size $5 \mathrm{~mm}$ or less). Only one isolate (L. plantarum FS11.2) showed maximum inhibition against $P$. alcaligenes whilst none of the isolate expressed maximum inhibition against $B$. cereus. The isolate earmarked as E. faecalis FS1.1 and L. plantarum FS 1.2 were most distinguished as they not only inhibited a majority of pathogens but also showed the maximum zone of inhibition.

\section{Earmarked most potential probiotic isolates}

Based upon the detailed investigation of desired probiotics attributes, three most promising $\mathrm{LAB}$ isolates which exhibited most of the features desirable for probiotics viz. Enterococcus faecium FS 1.1 (Fig. 1a), E. faecium FS 2.0 (Fig. 1b), and E. faecium FS 4.0 (Fig. 1c), were earmarked and identified based on $16 \mathrm{~S}$ rDNA sequence analysis (Fig. 1).
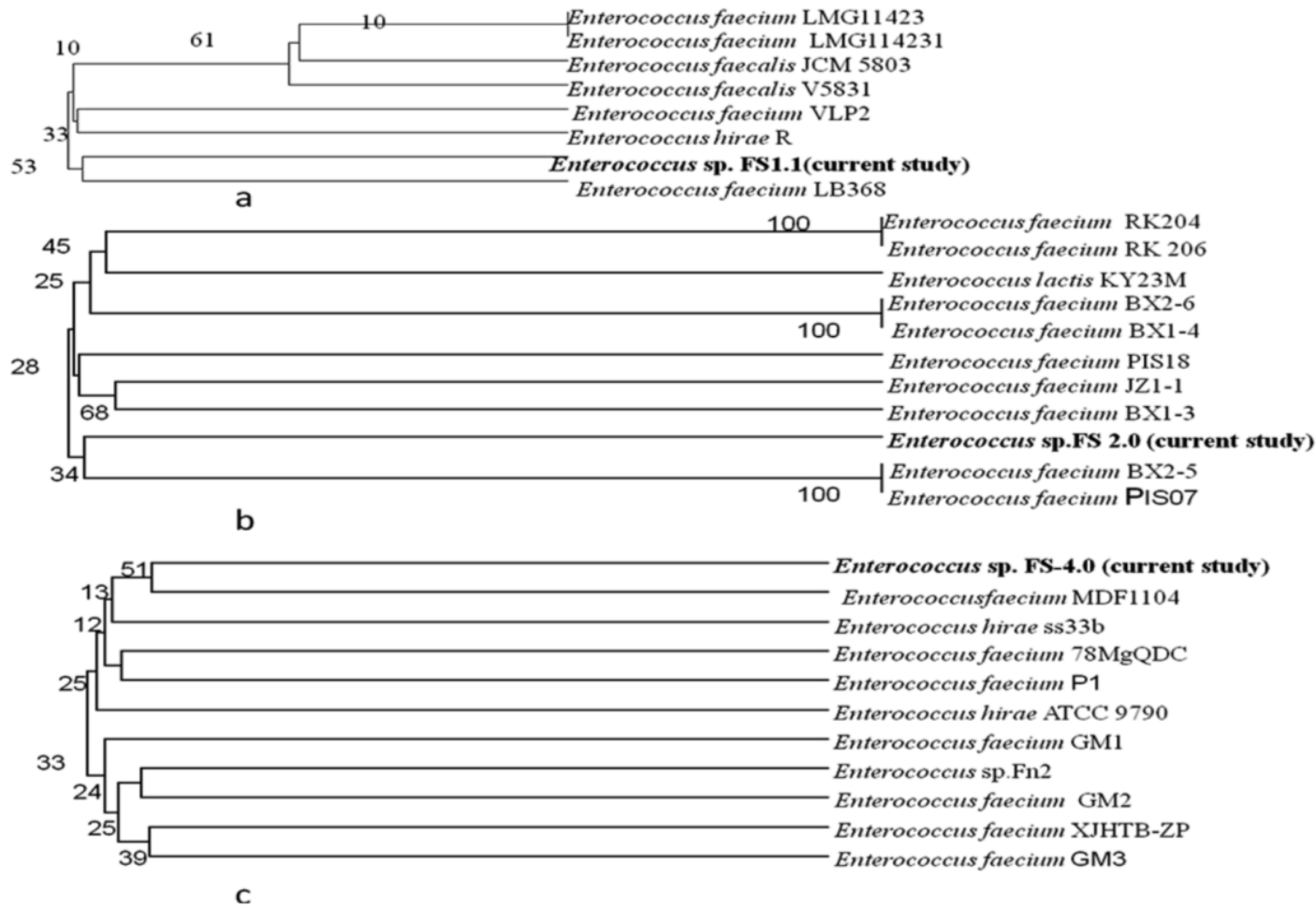

Figure 1 Identification of most promising LAB isolates Enterococcus faecium FS 1.1 (a), E. faecium FS 2.0 (b) and E. faecium FS 4.0 (c) by $16 \mathrm{~S}$ rDNA sequence analysis. Dendrogram were generated by using p-difference model and UPGMA statistical approach

\section{Fecal enzyme analysis ( $\beta$-glucuronidase and $\beta$-glucosidase)}

$\beta$-glucuronidase activity was higher in the formula fed infants as compared to the breast fed ones. The highest average activity of $\beta$-glucuronidase $(0.76$ mmoles/mg protein) was observed in formula fed infants (4-6 months) while the lowest activity ( $0.23 \mathrm{mmoles} / \mathrm{mg}$ protein) was observed in breast fed infants in the age band of 0-2 months (Fig. 2a). $\beta$-glucosidase activity analysis in breast fed and formula fed infants upto six months of age showed that breast fed infants had higher levels of $\beta$-glucosidase as compared to formula fed ones. The maximum $\beta$ glucosidase activity $(0.7 \mathrm{mmoles} / \mathrm{mg}$ protein) was reported from breast fed infants in the group of 4-6 months while the formula fed infants in 0-2 months of age exhibited lowest $\beta$-glucosidase activity $(0.23 \mathrm{mmoles} / \mathrm{mg}$ protein $)$ as presented in Fig. 2b). Furthermore, it was observed that activity of both the enzymes increase with increase in age of infant (Fig. 2c). 


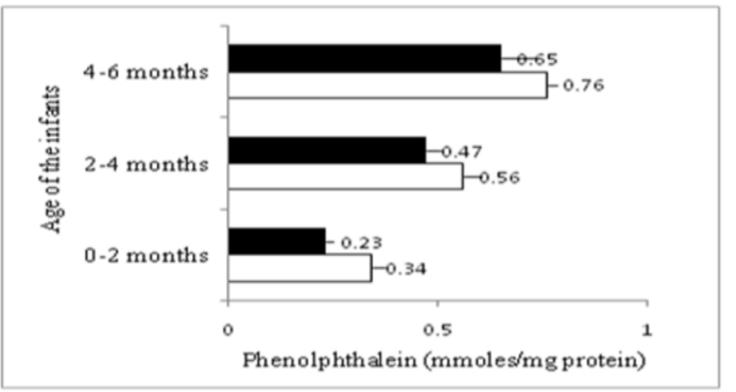

a

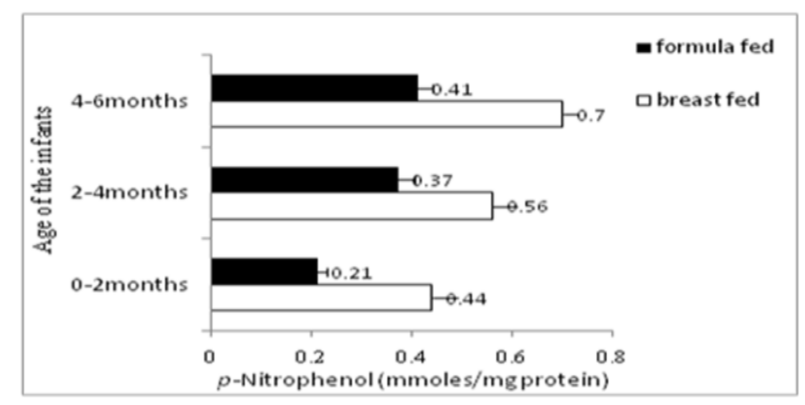

b

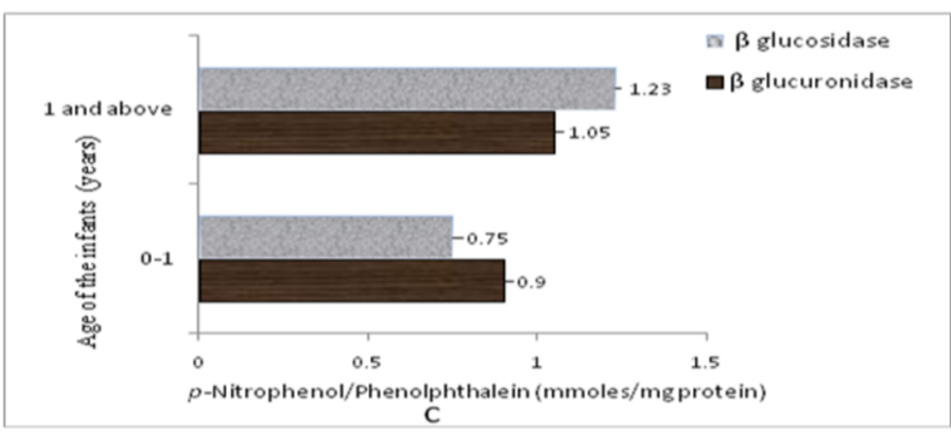

Figure 2 Fecal analysis for activity of $\beta$-glucuronidase (a) and $\beta$-glucosidase (b), activity variation of these enzymes with infant age (c)

\section{DISCUSSION}

The neonatal intestinal ecosystem is quite complex and performs variety of nutritive, immunological and protective functions (Turroni et al., 2012; Ozen and Dinleyici, 2015)). Generally Bifidobacterium spp. dominates in the gut of an infant borne out of vaginal mode of delivery and exclusively breast-fed relatively fewer enterobacteria and enterococci may be present but obligate anaerobes like Clostridium and Bacteroides spp. are quite rare (Fanaro et al. 2003; Langhendries 2005). However, the current study reports a higher number of lactobacilli and cocci as compared to the Bifidobacterium spp. (Table 1). This is contrary to the widely published reports that Bifidobacterium spp. constitutes the most abundant component of infant gut microflora (Turroni et al., 2012). However, there are some inconsistencies in literature regarding the prevalence, diversity and abundance of Bifidobacterium spp. in the infant intestinal microbiota. Initial bacterial colonization of the infant gut is strongly dependent on maternal flora, conditions and environment during delivery, and to certain extent nutritional habits (Fanaro et al., 2003). In addition, social, cultural and economic factors may have significant influence on infant initial gut colonization. Furthermore, intestinal microflora of infants born in rural, suburban and urban areas, and babies born at home and at hospitals do differ considerably (Fanaro et al., 2003). Variation in hygiene during delivery or during breast feeding, and antibiotics usage may be the probable reasons for differences in infants' initial microflora. In the Indian sub-continent particularly in the rural setup, there are rituals according to which the new born are given their first ever feed which may include honey, jaggery, glucose-water, plane water, top milk and gripe water etc. which may have considerable influence on initial gut microflora composition.

Inherent variations among probiotic strains with respect to their health benefitting attributes have been the motivation to investigate and target novel efficacious strains (Ozen and Dinleyici, 2015; Bajaj et al., 2015). Most important prerequisite for probiotics is to survive in the human gastrointestinal tract, and the ability to withstand low $\mathrm{pH}$, bile, salt and phenol (Bajaj et al., 2014). The probiotic strains investigated in the current study (Table 2) for potential application in the prevention/treatment of pediatric gastrointestinal diseases exhibited tolerance to wide $\mathrm{pH}$ range $(\mathrm{pH} 2-8)$, suggesting their ability to survive in different parts of the GI tract viz. stomach $(\mathrm{pH}<2)$, small bowel (proximal part $\mathrm{pH} 4-7$, distal part $\mathrm{pH} 7.8$ - 9) and large intestine $(\mathrm{pH} 4.0$ - 6.0). The $\mathrm{pH}$ resistance of probiotics strains has been reported to differ widely and is largely strain dependent (Bajaj et al., 2014; Bajaj et al., 2015). LAB isolates from dairy products grew well at $\mathrm{pH} 4$ (Jayakumar $\boldsymbol{e t}$ al., 2012) while those isolated from infant feces showed growth over broad $\mathrm{pH}$ of 1 - 9 (Pelinescu et al., 2011). Bile salts constitute one of the major factors that influence the viability of LAB in GI tract. Generally, the concentration of bile salts in bile varies from $0.8-4 \%$. In the current study, all the LAB isolates grew and survived at $2 \%$ of bile salt but only fewer thrived at $4 \%$ bile (Table 2) representing an advantage for the survival of these bacteria, once introduced in the GI tract, especially at the level of small bowel, where the concentration of bile salts is very high. Infant fecal isolates of $\mathrm{LAB}$ showed varying resistance to taurocholic acid sodium salt concentrations at 0.5 - 4\% (Pelinescu et al., 2011).
Resistance to phenol is an important probiotic characteristic as phenol can be formed by deamination of some aromatic amino acids by some bacteria and be able to exert bacteriostatic effect (Suskovic et al., 1997; Bajaj et al., 2014). Most of the LAB strains in this study grew well at $0.2-0.4 \%$ phenol (Table 2). Lactobacillus brevis, L. plantarum, and Pediococcus could decarboxylate the phenolic carboxylic acids, ferulic, and p-coumaric acids (Szwajgier and Jakubczyk, 2010). The LAB strains from milk products showed phenol tolerance up to $0.4-0.6 \%$ (Jayakumar et al., 2012).

Osmotolerance is one of the desired attribute for LAB strains intended for industrial applications (Adnan and Tan, 2007). During industrial fermentation using $\mathrm{LAB}$, alkali is pumped to prevent excessive reduction in $\mathrm{pH}$ due to lactic acid accumulation, which results in convertion of free acid to salt which in turn increase the osmotic pressure (Bajaj et al., 2014). Therefore, LAB strains must have high osmotolerance. All the LAB strains in the current study could hold on well up to $8 \%$ of salt levels but a further increase resulted in marked reduction in the growth and survival although some strains were able to do well even at $12 \%$ level (Table 2). LAB isolates from dairy sources showed growth and survival at high salt concentration $(6 \%)$ but growth ceased with further increase in salt concentration up to $8 \%$ (Jayakumar et al., 2012).

Hydrophobicity defines the adherence of bacteria to epithelial cells, and constitute an important probiotic property to prevent adherence and invasion of pathogens (Martin and Martin, 2009). Positive correlation between hydrophobicity-adhesion and aggregation-hydrophobicity (Li et al., 2008) suggests that bacteria with higher hydrophobicity have optimum auto-aggregation as well. Fecal LAB isolates in the present study showed varied level of hydrophobicity (Table 2). Similarly, LAB isolates from milk products showed variable levels of hydrophobicity with different organic solvents (Jayakumar et al., 2012). Heat treatment has been reported to increase the hydrophobicity (Collado et al., 2007).

Probiotics have been reported to produce exopolysaccharides (EPS) which may have potential applications in food industries as biothickeners, viscosifying, stabilizing, emulsifying or gelling agents; in addition, EPS have been reported to possess antitumour activity, immunomodulating bioactivity and anticarcinogenicity, thus may have health implications (Doleyres et al., 2005). In the present study, appreciable EPS producing ability of LAB isolates reflects their potential significance in food and pharmaceutical industries (Table 2). EPS producing ability of various Lactobacillus and Bifidobacterium strains isolated from the human intestinal microbiota has been investigated (Madiedo $\boldsymbol{e t}$ al., 2007).

High high serum cholesterol level is the major risk factor for coronary heart diseases, according to WHO by 2030 cardiovascular diseases will be the leading cause of death affecting about 23.6 million people around the world (WHO, 2009). Several pharmacological agents are available that effectively reduce cholesterol level but these are expensive and have severe side effects (Bliznakov, 2002). Probiotics due to their bile salt hydrolase activity may interact with hosts' bile salt metabolism and could reduce cholesterol levels (De Smet et al., 1998; Bajaj et al., 2015). Serum cholesterol is reduced due to its conversion into bile acids. LAB isolates in the current study exhibited potential cholesterol lowering ability (Table 2). Similar to current study, analysis of seven potential probiotics 
from human gut showed that Lactobacillus fermentum strain KC5b caused maximum cholesterol reduction (Dora et al., 2003; Bajaj et al., 2015).

Antimicrobial activity is a desirable probiotic attribute. In the present study, most of the potential probiotic isolates showed a potent inhibitory action against the pathogens of human importance. GI tract infections are one of the major causes of morbidity and mortality among infants/children worldwide; severe diarrhea and dehydration account for 15\% of total infants/children deaths per year (Lopez et al., 2001). Probiotics may be helpful in preventing and treating some types of bacteria-induced diarrhea because of their ability to alter the activity of the intestinal microflora and compete with potential pathogens (Marteau $\boldsymbol{e t}$ al., 2001; Bajaj et al., 2015) by the production of acids, hydrogen peroxides or by production of small peptides. The LAB isolates from snake gourd were reported to inhibit the growth of Shigella sonnei, Shigella. Staphylococcus aureus and E. coli (Awasthy et al., 2008). Five LAB isolates from dairy products showed antimicrobial potential against $E$. coli and $S$. aureus (Jayakumar et al., 2012) The enzymatic activities of gut microbiota has been identified as one of the indicator for global assessment of gut microbiota functions in the host, and has been reported to be associated with human health and disease status (Humblo et al., 2007). Activity of $\beta$-glucuronidase has been identified as a conserved function among bacteria colonizing the human gastrointestinal tract, which by uncoupling glucuronides, can deconjugate potential toxins increasing the formation of carcinogens in the bowel and promoting the enterohepatic recirculation of toxins, hormones and various drugs (Adlercreutz et al., 1976; Kuhn, 1998) in the body. Elevated levels of $\beta$-glucuronidase may be a primary factor in the etiology of colon cancer (Kuhn, 1998; Humblot et al., 2007) increased risk of breast cancer in postmenopausal women who have high estrogen levels (Key et al., 2011). In the current study, LAB isolates from the breast fed infants showed lower levels of $\beta$-glucuronidase which reflects the importance of breast feeding towards the development of a general well being of the infant (all LAB were from breast fed infants). $\beta$-glucosidases seems to have a more general role in the bioavailability of plant polyphenols and the extraction of energy from insoluble fibers and other indigestible carbohydrates (Han et al., 2007). The breast fed infants showed higher level of $\beta$-glucosidase as compared to the formula fed infants. The present study in general portrays variation in fecal enzyme levels of infants with respect to mode of delivery, diet and age (Mykkanen et al., 1998) also attributed a change in age and adoption of an adult type diet towards the variation in fecal enzyme levels. Enzymes in LAB isolates from human feces were studied and it was reported that the activity of $\beta$ glucuronidase increased with age while that of $\beta$-glucosidase decreased (Mroczynska and Libudzisz, 2010)

\section{CONCLUSION}

Current study concludes that Lactobacillus spp. constitute the most predominan spp. ( $L$. plantarum being the most abundant) contrary to the previous reports which claim Bifidobacterium spp. to be the predominant. Several of the LAB isolates from infant gut exhibited tolerance to $\mathrm{pH}, \mathrm{NaCl}$, bile and phenol concentration indicating their ability to thrive in the gut environment. Some of the LAB isolates possessed excellent probiotic features such as high hydrophobicity, cholesterol lowering ability, EPS producing ability and antagonistic activity against pathogens, but three isolates (Enterococcus faecium FS 1.1, E. faecium FS 2.0, E. faecium FS 4.0) showed most promising potential as probiotics. Breast fed infants showed lower level of $\beta$-glucuronidase, and higher level of $\beta$-glucosidase as compared to formula fed ones which underlines the health benefits of breast feeding for infants. Further in depth studies must be conducted to assess the potential of LAB isolates for perspective application as infant probiotics.

Acknowledgements: Dr. Bijender Kumar Bajaj gratefully acknowledges VLIRUOS for Short Research Stay (SRS-Scholarship) to visit Department of Bioscience Engineering, University of Antwerp, Antwerp, Belgium; Ms Konika Razdan is grateful to Council of Scientific and Industrial Research (CSIR), Govt. of India, for Senior Research Fellowship (SRF) for Ph.D.; Authors thank Director, School of Biotechnology, University of Jammu, Jammu, for necessary Laboratory facilities, and Dr. Ashok K. Gupta, Govt. Medical College Jammu, for assisting in sample collection.

\section{REFERENCES}

ADLERCREUTZ, H., MARTIN, F., PULKKINEN, M., DENCKER, H., RIMER, U., SJOBERG, N.O., TIKKANEN, M.J.1976. Intestinal metabolism of estrogens. J. Clin. Endocrin. Metab. 43, 497-505. http://dx.doi.org/10.1210/jcem-43-3-497

ADNAN, A.F.M., TAN, I.K.P. 2007. Isolation of lactic acid bacteria from Malaysian foods and assessment of the isolates for industrial potential. Bioresour. Technol., 98, 1380-1385. http://dx.doi.org/10.1016/j.biortech.2006.05.034

ASWATHY, R.G., ISMAIL, B., JOHN, R.P., NAMPOOTHIRI, K.M. 2008. Evaluation of the probiotic characteristics of newly isolated lactic acid bacteria Appl. Biochem. Biotechnol.,151, 244-255. http://dx.doi.org/10.1007/s12010-008$\underline{8183-6}$
BAJAJ, B.K., ANDRABI, T., CLAES, I.J.J., LEBEER, S. 2014. Bioprospecting for functionally-proficient potential probiotics. Curr. Nutr. Food Sci., 10, 251263. http://dx.doi.org/10.2174/1573401311666141215212331

BAJAJ, B.K., CLAES, I.J.J., LEBEER, S. 2015. Functional mechanisms of probiotics. J. Microbiol. Biotechnol. Food Sci. 4, 321-327. http://dx.doi.org/10.15414/jmbfs.2015.4.4.321-327

BARONE, M., LOFANO, K., DE-TULLIO, N., LICINO, R., ALBANO, F., DI-LEO, A. 2012. Dietary, endocrine, and metabolic factors in the development of colorectal cancer. J. Gastrointest. Cancer., 43, 13-19. http://dx.doi.org/10.1007/s12029-011-9332-7

BLIZNAKOV, E.G.2002. Lipid-lowering drugs (statins), cholesterol, and coenzyme Q10. The Baycol case- a modern Pandora's box. Biomed Pharmacother., 56, 56-59. http://dx.doi.org/10.1016/s0753-3322(01)00150-0

COLLADO, M.C., SURONO, I., MERILUOTO, J., SALMINEN, J. 2007. Indigenous dadih lactic acid bacteria: cell-surface properties and interactions with pathogens. J. Food Sci., 72, M89-93. http://dx.doi.org/10.1111/j.17503841.2007.00294.X

DE SMET, I., DE BOEVER, P., VERSTRAETE, W. 1998. Cholesterol lowering in pigs through enhanced bacterial bile salt hydrolase activity. Br. J. Nutr., 79 , 185-194. http://dx.doi.org/10.1079/bin19980030

DOLEYRES, Y., SCHAUB, L., LACROIX, C. 2005. Comparison of functionality of exopolysaccharides produced in situ or added as bioingredients on yoghurt properties. J. Dairy Sci., 88, 4146-4156. http://dx.doi.org/10.3168/jds.s0022-0302(05)73100-3

DORA, I.A., ANNE, P., MCCARTNEY, L., GIBSON, G.R. 2003. An in vitro study of the probiotic potential of a bile-salt-hydrolyzing Lactobacillus fermentum strain, and determination of its cholesterol-lowering properties. Appl. Environ. Microbiol., 69, 4743-4752. http://dx.doi.org/10.1128/aem.69.8.47434752.2003

DUBOIS, M., GILLES, K., HAMILTON, J., REBERS, P., SMITH, F. 1956 Colorimetric method for determination of sugars and related substances. Anal. Chem.,28, 350-356. http://dx.doi.org/10.1021/ac60111a017

FANARO, S., CHIERICI, R., GUERRINI, P., VIGI, V. 2003. Intestinal microflora in early infancy: composition and development. Acta Paediatr. Suppl., 91, 48-55. http://dx.doi.org/10.1111/j.1651-2227.2003.tb00646.x

FREEMAN, H.J. 1986. Effects of differing purified cellulose, pectin, and hemicellulose fiber diets on fecal enzymes in 1, 2-dimethylhydrazine-induced rat colon carcinogenesis. Cancer Res., 46, 552-553. http://cancerres.aacrjournals.org/content/46/11/5529.full.pdf

FRENGOVAA, G.I., SIMOVA, E.D., BESHKOVA, D.M., SIMOV, Z.I. 2002. Exopolysaccharides produced by lactic acid bacteria of kefir grains. $Z$. Naturforsch., 57, 805-810. http://dx.doi.org/10.1515/znc-2002-9-1009

HUMBLOT, C., MURKOVIC, M., RIGOTTIER-GOIS, L., BENSAADA, M., BOUCLET, A., ANDRIEUX, C., ANBA, J., RABOT, S. 2007. $\beta$-Glucuronidase in human intestinal microbiota is necessary for the colonic genotoxicity of the food-borne carcinogen 2-amino-3-methylimidazo[4,5-f]quinoline in rats. Carcinogenesis, 28, 2419-2425. http://dx.doi.org/10.1093/carcin/bgm170

HUSSEY, S., WALL, R., GRUFFMAN, E., O'SULLIVAN, L., RYAN, C.A. MURPHY, B., FITZGERALD, G., STANTON, C., ROSS, R.P. 2011 Parenteral antibiotics reduce bifidobacterial colonization and diversity in neonates. Int. J. Microbiol., http://dx.doi.org/10.1155/2011/130574

HAN, X., SHEN, T., LOU, H. 2007. Dietary polyphenols and their biological significance. Int. J. Mol. Sci. 8, 950-958. http://dx.doi.org/10.3390/i8090950 ISHIBASHI, N., YAESHIMA, T., HAYASAWA, H. 1997. Bifidobacteria: their significance in human intestinal health. Mal. J. Nutr., 3, 149-159. http://nutriweb.org.my/publications/mjn003_2/mjn3n2_art6.pdf

JAYAKUMAR, B.D., KONTHAM, K.V., NAMPOOTHIRI, K.M. 2012. Newly isolated lactic acid bacteria with probiotic features for potential application in food industry. Appl Biochem Biotechnol., 167,1314-1324. http://dx.doi.org/10.1007/s12010-012-9561-7.

KEY, T.J., APPLEBY, P.N., REEVES, G.K., RODDAM, A.W., HELZLSOUER, K.J.2011. Circulating sex hormones and breast cancer risk factors in postmenopausal women: reanalysis of 13 studies. Br. J. Cancer., 105, 709-722. http://dx.doi.org/10.1038/bjc.2011.254

KUHN, J.G. 1998. Pharmacology of irinotecan. Oncol. 12, 39-42. http://dx.doi.org/10.1358/dot.1998.34.9.485276

LANGHENDRIES, J.P. 2005. Early bacterial colonisation of the intestine: why it matters. Ital. $J . \quad$ Pediatr., 31, 360-369. http://www.ncbi.nlm.nih.gov/pubmed/17079124

LI, X.J., YUE, L.Y., GUAN, X.F., QIAO, S.Y. 2008. The adhesion of putative probiotic lactobacilli to cultured epithelial cells and porcine intestinal mucus. $J$ Appl. Microbiol., 104, 1082-1091. http://dx.doi.org/10.1111/j.1365 2672.2007.03636.x

LOPEZ, AD., MATHERS, C.D., EZZATI, M., JAMISON, D.T., MURRAY, C.J. 2006. Global and regional burden of disease and risk factors, 2001: systematic analysis of population health data. Lancet., 367, 1747-1757. http://dx.doi.org/10.1016/S0140-6736(06)68770-9

MACKIE, R.I., SGHIR, A., GASKINS, H.R. 1999. Developmental microbial ecology of the neonatal gastrointestinal tract. Am. J. Clin. Nutr., 69, 1035S-45S http://www.ncbi.nlm.nih.gov/pubmed/10232646 
MADIEDO, P.R., MORENO, J.A., SALAZAR, N., DELGA DO, S., MAYO ,B., MARGOLLES ,A., DE LOS REYES-GAVILÁN, C.G. 2007. Screening of exopolysaccharide-producing Lactobacillus and Bifidobacterium strains isolated from the human intestinal microbiota. Appl. Environ. Microbiol., 73, 4385-4388. http://dx.doi.org/10.1128/aem.02470-06

MARTEAU, P.R., DE VRESE, M., CELLIER, C.J., SCHREZENMEIR, J. 2001. Protection from gastrointestinal diseases with the use of probiotics. Am. J. Clin. Nutr., 73, 430S- 436S. http://www.ncbi.nlm.nih.gov/pubmed/11157353\#

MARTIN, P.S., MARTIN, O.S. 2009. Feeding strategies for the control of Salmonella in pigs In: Gibson Glenn R (eds) Food Science, and Technology Bulltein: Functional food. IFIS publishing, Shinfield., pp, 39-50.

MARTNEZ, E.B., FLIX, E.A., URIARTE, A.P., PLASCENCIA, G.Y. 2012

Fructose 6-phosphate phosphoketolase activity in wild-type strains of Lactobacillus, isolated from the intestinal tract of pigs. Appl. Biochem. Microbiol., 48, 444-451. http://dx.doi.org/10.1134/s000368381205002x

MC INTOSH, F.M., MAISON, N., HOLTROP, G., YOUNG, P., STEVENS V.J., JOHNSTONE, I.J., AM, LOBLEY, G.E., FLINT, H.J., LOUIS, P. 2012 Phylogenetic distribution of genes encoding beta-glucuronidase activity in human colonic bacteria and the impact of diet on faecal glycosidase activities. Environ. Microbiol., 14, 1876-1887. http://dx.doi.org/10.1111/j.1462-2920.2012.02711.x MROCZYNSKA, M., LIBUDZISZ, Z. 2010. Beta-glucuronidase and betaglucosidase activity of Lactobacillus and Enterococcus isolated from human $\begin{array}{lllll}\text { feces. } & \text { Pol. } & J & \text { Microbiol., } & \text { 59, }\end{array}$ http://www.pjm.microbiology.pl/archive/vol5942010265.pdf

MYKKANEN, H., LAIHO, K., SALMINEN, S. 1998. Variations in fecal bacterial enzyme activities and associations with bowel function and diet in elderly subjects. J. Appl. Microbiol., 85, 37-41. http://dx.doi.org/10.1046/j.13652672.1998.00454.X

NEWBURG, D.S. 2005. Innate immunity and human milk. J. Nutr., 135, 13081312. http://www.ncbi.nlm.nih.gov/pubmed/15867330\#

O'TOOLE, P.W., CLAESSON, M.J. 2010. Gut Microbiota: Changes throughout the life span from infancy to elderly. Int. Dairy J., 20, 281-291. http://dx.doi.org/10.1016/j.idairyj.2009.11.010

OZEN, M., DINLEYICI, E.C. 2015. Foreword: All things considered about probiotics, prebiotics and intestinalmicrobiota in children - from bench to bedside. Benef. Microb., 6,153-157. http://dx.doi.org/10.3920/bm2014.x002

PATIL , M.M., PAL, A., ANAND, T., RAMANA, K.V.2010. Isolation and characterization of lactic acid bacteria from curd and cucumber. Indian $J$ Biotechnol., 9 9, 166-172. http://nopr.niscair.res.in/bitstream/123456789/7795/1/IJBT\%209(2)\%20166-

172.pdf

PELINESCU, D., CHIFIRIUC, M.C., DITU, L.M., SARBU, I., BLEOTU, C., VASSU, T., STOICA,I., LAZAR, V., CORCIONIVOSCHI, N., SASARMAN, E. 2011. Selection and characterization of the probiotic potential of some lactic acid bacteria isolated from infant feces. Rom. Biotech. Lett., 16, 6178-6189. http://www.rombio.eu/rbl3vol16/18\%20Pelinescu.pdf

RUDEL, L.L., MORRIS, M.D. 1973. Determination of cholesterol using $o$ $\begin{array}{llll}\text { phthalaldehyde. } \quad J . & \text { Lipid } & \text { Res., }\end{array}$ http://www.jlr.org/content/14/3/364.full.pdf

SALMINEN, S., GUEIMONDE, M., ISOLAURI, E. 2005. Probiotics that modify disease risk. J. Nutr., $135, \quad 1294-1298$ http://jn.nutrition.org/content/135/5/1294.full.pdf+html

SUSKOVIC, J., BRKIC, B., MATOSIC, S., MARIC, V. 1997. Lactobacillus acidophilus M92 as potential probiotic strain. Milchwissenschaft., 52, 430-435.

SZWAJGIER, D., JAKUBCZYK, A. 2010. Biotransformation of ferulic acid by Lactobacillus acidophilus K1 and selected Bifidobacterium strains. Acta Sci. Pol. Technol. Aliment., 9, 45-59. http://www.food.actapol.net/pub/4_1_2010.pdf

TURRONI, F., PEANO ,C., PASS, D.A., FORONI ,E., SEVERGNINI, M. CLAESSON, M.J., KERR ,C., HOURIHANE, J., MURRAY, D., FULIGNI, F., GUEIMONDE, M., MARGOLLES, A., DE BELLIS, G., O'TOOLE, P.W. VAN SINDEREN, D., MARCHESI, J.R, VENTURA, M.B. 2012. Diversity of bifidobacteria within the infant gut microbiota. Plos One., 7, e36957. http://dx.doi.org/10.1371/journal.pone.0036957

WENG, M., WALKER, W.A. 2006. Bacterial colonization, probiotics, and $\begin{array}{llll}\text { clinical disease. } & J . & \text { Pediatr., } & 149,\end{array}$ http://dx.doi.org/10.1016/j.jpeds.2006.06.061

WHO., 2009. Cardiovascular Disease, Fact sheet no. 317, WHO, Geneva, Switzerland, 2009, http://www.who.int/mediacentre/factsheets/fs317/en/

ZEIGER, R.S. 2003. Food allergen avoidance in the prevention of food allergy in infants and children. Pediatr., 111, 1662-1671. http://onlinelibrary.wiley.com/doi/10.1034/j.1398-9995.2001.00933.x/full ZINEDINE, A., FAID, M. 2007. Isolation and Characterization of Strains of Bifidobacteria with Probiotic Proprieties In vitro. World J. Dairy Food Sci., 2, 28-34. http://www.idosi.org/wjdfs/wjdfs2(1)/5.pdf 